\title{
The Concept of Sustainable Development in the Mediterranean: Emergence and Recurrence
}

\section{Lucien Chabason, Athens}

\section{Historical aspects}

When, living in Greece, one re-reads Chateaubriand's journey from Paris to Jerusalem, that also took him to Athens which had little more than 20000 inhabitants then, and when one thinks of modern-day Attica with its 4-5 million inhabitants, $40 \%$ of national industry the question of sustainable development comes to mind, with an eye to the past. A retrospective view is possible because of the accumulated knowledge of archaeology, history, but also travellers' accounts. Think of the description of the banks of the Ilissos in Plato's Phaedra, or erosion phenomena in Kritias by the same author. There is also description of Greece written by PAUSANIAS at the beginning of the first millenium.

Specific approaches to sustainable development such as the «carrying capacity» of the islands would appear to be particularly when one considers the fate of a small island such as Delos, a sanctuary and major trading place in Antiquity which, uninhabited today, had some 10000 permanent inhabitants over $3 \mathrm{~km}^{2}$, or an average density of several thousand inhabitants. Archaeological research carried out by the French School in Athens has shown how the system for collecting and storing water worked both collectively and for individuals, and amazingly efficient. This brings us to an essential Mediterranean topic - water.

Modern literature on sustainable development puts a strong emphasis on the availability of water resources and their correct usage. Each year a major world conference is held on this subject and impressive figures are published both on increases in consumption, the spread of areas where supply is threatening to dry up, and wastage. Irrigation-based intensive agriculture is flagged up as the main pressure-inducing factor. There seems to be a continuing trend towards the exhaustion of available resources compared with the number of inhabitants.

Looking back into the past, however, the scale of problems faced by Mediterranean towns and agriculture way back in Antiquity becomes evident, for example, the size of conveyance and storage structures in Carthage, Nikopolis, Pergamon, Nimes, Athens, Rome and Lesbos, the development of hydraulic engineering and the perfecting of techniques, particularly the syphon. Consider also how specific the legal rules were governing the use of public water, and the strict control mechanisms for rational use, particularly in agriculture. Thus we stand face to face with history and the role it potentially plays in environmental reasoning, and in the limitations issue.
The history of the physical relationship between man and nature is approached from completely opposite angles. Some feel that the decline of civilisations is largely linked to natural resources being used up, particularly soil and forests (Dorst 1971). This hypothesis is strongly criticised by HERVÉ LE BRAS in «The Limits of the Planet» (Le Bras 1994) which questions the relevance of the carrying capacity concept, and criticises the automatic transfer of concepts stemming from the biology of populations to the functioning of human societies. Others - traces of this apologetic vision are already to be found in SoPHOCLES' «Antigone» - feel that history reveals the ability of human societies to overcome the problems of natural limits due to technology and appropriate social, economic and political organisation. There is no problem which cannot be solved; ecological impact - if recognized - can also be controlled by the ways and means at our disposal. It is the problem of substitution of technological for natural capital which characterises «low sustainability» (GODARD 1994).

People who talk of limited resources, the irreversible destruction of the environment and the unfair handingon of burdens to future generations are thus accused of belonging to the same spectrum as those who rejected the steam engine, railroad and the Eiffel Tower, and those who were against Haussman's town planning in Paris; they are singled out as those who, in the modern age, would like to see «a return to the oil lamp».

In this context of clear opposition where, within leading and intellectual circles in France, eco-sceptical, not to say eco-negating visions have the upper hand, history could help us to put questions of sustainable development into perspective, to measure their progress, to identify any potential break-points, to study the historical relationships between ecological facts and their social representation, and to take account of constructivism (which seems important) and the ecological relativism beneath which it lies. In this respect it is essential to go back to neolithic times when the first mass wave of anthropisation of the environment occurred, and thence to Antiquity.

Although there is quite some literature available, there are not many facts, however. As CORINNE BECK states, «it will be archaeology... which will gradually bring environmental concerns into historical discussion», although later on she adds on water and its uses that «historians and archaeologists are still not strongly enough committed to this issue» (BECK 1998). Particular reference should be made to J. Donald Hughes' work: «Pan's travail: Environmental problems of the ancient Greeks and Romans» (Hugues 1994), and that of DoRA 
P. Crouch: «Water Management in Ancient Greek Cities» (CROUCH 1993), and Robert Martin: «Town Planning in Ancient Greece» (MARTIN 1956). Concerning the transformation of the rural landscape, deforestation and soil erosion, mention should be made of $\mathrm{J}$. GuILAINE: «In favour of Agricultural Archaeology" (GuILAINE 1991); the report of the Symposium on «Deforestation, erosion and ecology in the ancient Mediterranean» which was organised by the Smithsonian Institution, NMNH - Washington D.C. in 1978 and «Man and the Mediterranean Forest» of J.V. THIRGOOD (THIRGOOD 1981).

\section{The recent appearance of the concept of sustainable development in the Mediterranean}

It quickly became clear that the Mediterranean was potentially one of the regions of the world in which the concept of sustainable development could logically be implemented. It is characterised by rapid development, scarcity of natural resources, different levels of devel- opment between riparian states, the relevance of the question of equity, and also because of spectacular developments which are specific to the region, such as tourist and urban development, and competition for the coastal region. When the first efforts were made to protect the Mediterranean in the early 70s, the main risks were those of major accidents at sea and accidents involving oil tankers. Studies quickly showed, however, that most pollution came from land-based sources, and activities.

The protection of the Mediterranean was one of the first achievements of the Stockholm Conference in 1972. Although this first major world meeting on the environment made no mention of sustainable development, eco-development was already on peoples' lips. UNEP was created soon afterwards, not as a full-blown United Nations Agency like the ones in Geneva, for example WHO, but rather as a programme with a so-called catalytic role. In other words, it was not expected to manage environmental issues itself, but rather to lobby the main U.N. agencies to get them to discuss and work together on environmental problems. UNEP thus expressed at

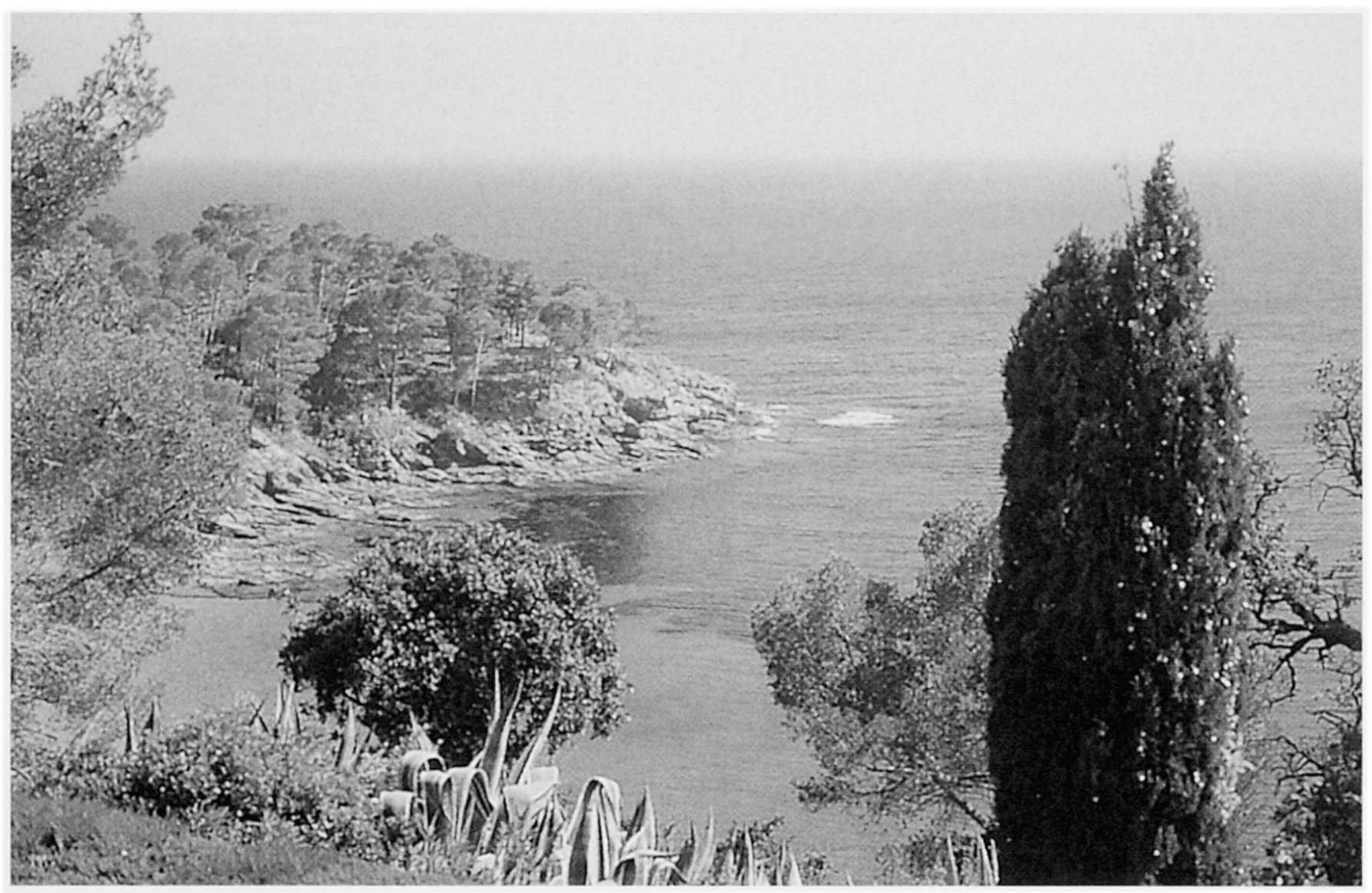

Fig. 1: A protected landscape on the French Mediterranean coast: Domain of Rayol (Rayol Canadel, Var) Un paysage protégé sur la côte méditerranéenne française: le Domaine du Rayol (Rayol Canadel, Var) Geschïtzte Landschaft an der französischen Mittelmeerküste. Die Domäne Rayol (Rayol Canadel, Var) Source: Les Editions Aris 
the international level the vision adopted in 1971 by France, for example, when she set up a small ministry for the environment devoid of regional services, without a body of civil servants, and with no powers apart from trying to influence the practices of the major ministries. The ministry for the environment worked on this basis until 1990, until the National Plan for the Environment attempted to inject more confidence and build up the regional services in particular which had not existed until then. Neither the nature nor the institutional concept of UNEP have changed - it continues to be a catalytic structure with both the advantages and limitations this implies. One of UNEP's first achievements was to launch the «regional seas», spearheaded by the Mediterranean with the Mediterranean Action Plan (MAP) and its legal framework - the Barcelona Convention.

\subsection{The Barcelona Convention}

One major political question raised by environment policy is whether the environment should be managed in ad hoc areas, based on ecological logic, or whether preexisting political and administrative areas at the global, continental, national or local level etc. should shoulder environmental issues. In France, for example, water agencies were established for the different basins, in other words, ecological areas were identified around which the political and administrative structures were encouraged to be set up.

$\mathrm{A}$ «regional sea» is an environmental area around which the riparian states and various players are invited to come together in order to organise its protection (see Fig. 1). When the «regional seas programme» was launched, people still believed in the management of common property; the age of privatisation had not yet dawned. HARDIN's 1968 article on «The Tragedy of the Commons» (DoBson 1991) was well known by then, but the environmentalist community rejected the author's concepts as an inappropriate vision. 6 miles was the officially accepted extent of territorial waters, and there were still no exclusive economic areas, which were only introduced by law of the sea under the Montego Bay Convention in 1982.

The Mediterranean was the first regional sea to be established and to be covered by an international treaty called the Barcelona Convention on the protection of the Mediterranean Sea against pollution. The Convention has six regulatory programs covering specific themes. One restricts and now bans dumping, another aims at reducing land-based inputs, a third deals with information and mutual cooperation between states in case of accidents at sea, whilst a fourth covers the setting-up of specially protected areas in the Mediterranean for the protection of species and habitats. A fifth deals with controlling offshore activities and a sixth with the transportation of hazardous waste in the Mediterranean.
The institutional structures needed to manage the Convention have been set up by member countries, the twenty countries around the Mediterranean basin plus the European Union. The Convention has its own management including the Athens-based Coordinating Unit which acts as Secretariat, and six regional activity centres. One of the original features of the Barcelona Convention is that from the very beginning a structure was introduced to study the interaction between development and the environment. This is the Blue Plan, which is based in Sophia Antipolis, France.

\subsection{The Blue Plan's work}

It was not enough merely to tackle the problems of the marine environment - a series of studies on the expected environmental impact of the development of Mediterranean countries was also launched. This was the age of the Blue Plan scenarios, drawn up for the years 2000 and 2005, and published in 1989 (GRENON \& BATISSE 1989). It is interesting to study these scenarios because they cover approaches which are already included in the BRUNDTLAND report. Emphasis is laid first and foremost on population development as a major source of pressure on resources, as are urbanisation, the lack of joint organisational control of activities regarding urban and industrial development, tourism and natural habitat development in coastal areas. 125 pollution «hot spots» have been identified in the Mediterranean with considerable pressure on the coastal and marine environment and a situation of environmental crisis or semi-crisis exists.

Given these observations, scenarios which could be qualified as "scenarios of the impossible» have been drawn up. These are called trend scenarios (what will happen if present trends continue). The other scenario is called the «controlled development» scenario, which would now be called sustainable development. This work created a very good impression within the international community and was used by the Rio Conference an important input from the Mediterranean. The years from 1990-1995 saw a proliferation of studies on issues of sustainable development resulting from:

- an atmosphere of international detente

- a decrease in military spending

- the promotion of concepts such as internal democracy, human rights, the protection of women, the rights of non-governmental organisations

- the development of international law.

During this period the Mediterranean Commission on Sustainable Development was set up and approved in 1995. This body is made up of 36 members and acts as an advisory body within the framework of the Barcelona Convention. It places representatives of countries, environmental NGOs, socio-economic players and representatives of local authorities on an equal footing. 


\section{The work of the Mediterranean Commission on Sustainable Development (MCSD)}

The first issue to be tackled by the Commission will come as no surprise. High priority was given to water, tourism, the sustainable management of coastal areas, and suitable environmental indicators.

\subsection{Tourism}

Tourism lies at the very heart of sustainable development, the question being whether or not it is possible to maintain the economic advantages of tourism whilst solving the environmental problems it causes. This question is of vital importance in the world's leading tourist region which is visited every year by 250 million tourists from abroad. There is no doubt that waste generated by tourism could be better managed and efforts made to control water and energy consumption and basically whatever tourism brings in its wake. Also, hotels, property and leisure complexes and road infrastructure for tourism are irreversible and merit particular attention since they clash so directly and harshly with the sites to be protected. The natural coastal areas of great aesthetic and ecological value (dunes, beaches and coastal forests) which deserve to be preserved are precisely the ones singled out by planners and developers for commercial development. The example of the relationship between the environment and tourism shows how limited and overly optimistic the win-win approach is to which the World Bank and its theory-makers subscribe. It would be an illusion to believe that the environment could be managed whilst reaping the dividends of tourist development which depends on a high quality environment.

Environmental protection must be an end into itself and the result of a clear will. Again, it would be an illusion to believe that economic players, particularly in tourism, will shoulder environmental issues themselves. It will take a strong political will to prevent the natural sites around the Mediterranean from being colonised by tourist complexes.

\subsection{Water}

Water is another major issue, the importance of which has been defined and supported by the Blue Plan. For this the Blue Plan uses an indicator of usage (see Fig. 2, 3 ). This is an index which takes the quantity of water used as its numerator and the average for renewable water resources over a given period as its denominator. Countries are classified according to a scale which exceeds $100 \%$ for some (Israel, Libya, and Malta), whilst getting close to the mark for others (Tunisia, Cyprus and Algeria). This indicates that a level has been reached where annual usage exceeds renewable resources.

A study of water management practices, however, shows that the countries which are most affected by the problem of resources are indeed able to react to it by increasing water supply:

either by constructing huge dams, as in the case of Turkey,

or by diverting some of the water from one basin to feed others (the Nile, the Acheloos in Central Greece, the Rhône near Spain),

or by pumping from the fossil layers and taking the water to populated areas (the Libyan «man-made river» project),

or, finally, by developing desalination techniques (Malta, Libya and Cyprus).

Modern desalination techniques produce water for human consumption for 1-1.5 Euros per $\mathrm{m}^{3}$, which is acceptable from a socio-economic point of view. The Blue Plan is reticent about this type of response which it feels is non-sustainable both physically (in the case of the fossil layers) and ecologically, instead advocating better management of water demand for agricultural irrigation in particular, which accounts for between 70 and $80 \%$ of water consumption, depending on the country.

This supports a diversity of viewpoints

- a neo-Malthusian vision, according to which water will become the limiting factor of development,

- a Promethian vision of planning aimed at balanced land development based on systems for transferring water and inter-linkage which will make it possible to meet demand,

- a geostrategic vision according to which water will be one of the main causes of tension and conflict in the third millennium,

- and finally, an economic vision according to which, as in the energy field, there is no actual shortage, but rather bad economic management due in particular to the malfunctioning of markets, the non-recognition of ownership rights, and the abuse of subsidies for water consumption and irrigated farming.

A well-functioning market is based on comparative advantages. This would allow both for the cost of water and for agro-food products the workings of the markets to avoid incorrectly irrigating non-competitive areas and to produce food resources, particularly cereals, best in areas which are naturally well supplied with water. It would be more reasonable to switch products rather than to transfer a scarce natural resource at vast expense.

Let us now add the environmental vision to these four categories, which sees water not merely as a resource for human activity, but also as a wildlife habitat which should be conserved and managed in a sustainable fashion. Can the history of resources and water usage shed some light on these lively discussions? Quantitively speaking, historical data is very limited (BECK 1998). A study of water provision and legal rules governing its usage in Greece and Rome reveals, however, 
- development of the technical and economic ability to mobilise water resources for human consumption and irrigation more than 25 centuries ago, probably as early as neolithic times,

- water consumption in urban (fountains) and societyrelated (spas and baths) amenities which used up to $80 \%$ of Rome's water,

- precise legal rules on usage to avoid wastage.

According to Plorin, the head of the water services in Rome in VITRUVIUS' times, Rome had 1200000 inhabitants who consumed on average $600000 \mathrm{~m}^{2}$ per day, or 500 litres per person per day. Works of art had a turn-

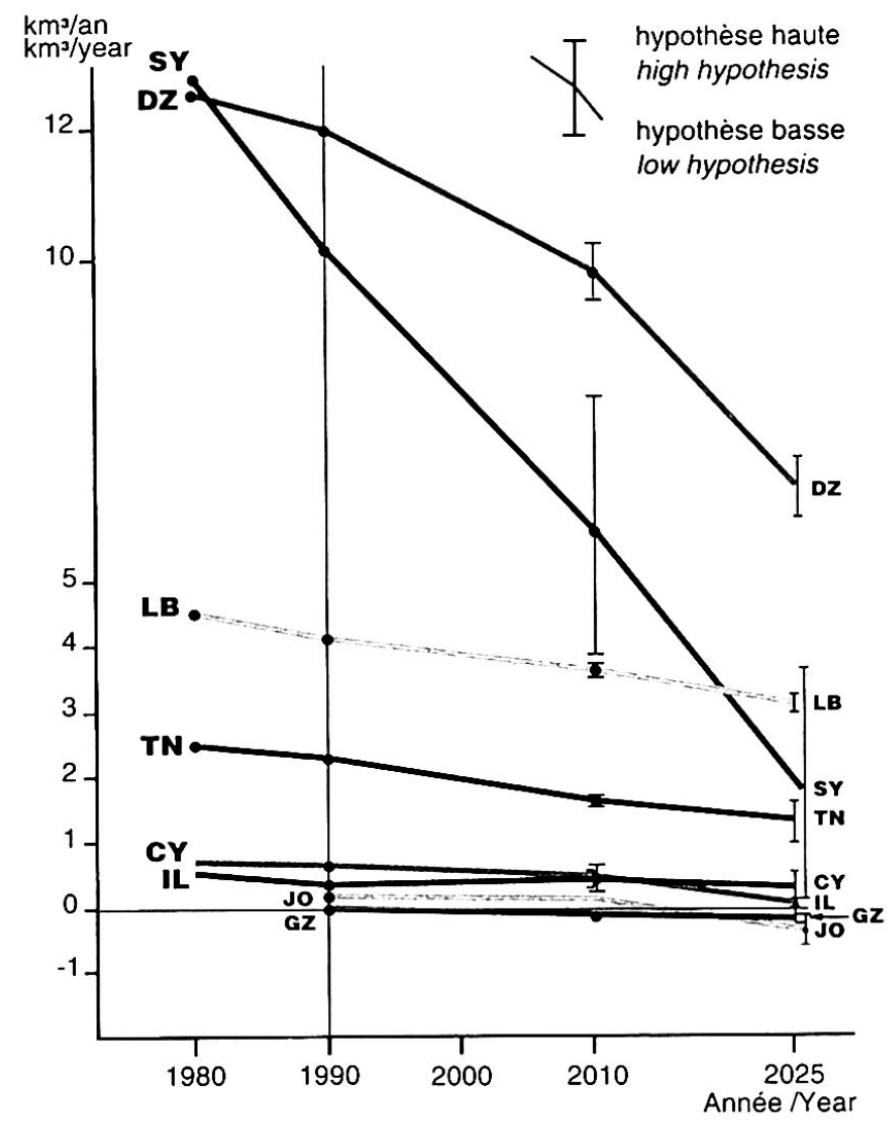

Fig. 2: Estimated water supplies in 2010 and 2025

Disponibilités nettes en eau aux horizons 2010 et 2025 Geschätze Wasserressourcen in den Jahren 2010 und 2025

Source: L'eau en région méditerranéenne, Centre d'activités régionales du Plan Bleu, Marseille, novembre 1996, p. 48. over capacity of $1 / 3$ of the Tiber's average flow. It is interesting to compare these figures with the ones published by Jean-Pierre Goubert (Goubert 1986). He notes that consumption in Paris in the late 18th century did not exceed 10 litres per inhabitant per day, and then exploded due to progress in hygiene to reach 200 litres/ day at the end of the second empire. The advent of the bathroom and the washing machine would push this figure much higher in the 20th century.

The history of water consumption, then, does not follow a linear path; it is clear that water consumption in Pericles' time in Athens was much higher than 20 centuries later during the OtToman period, or in the Paris

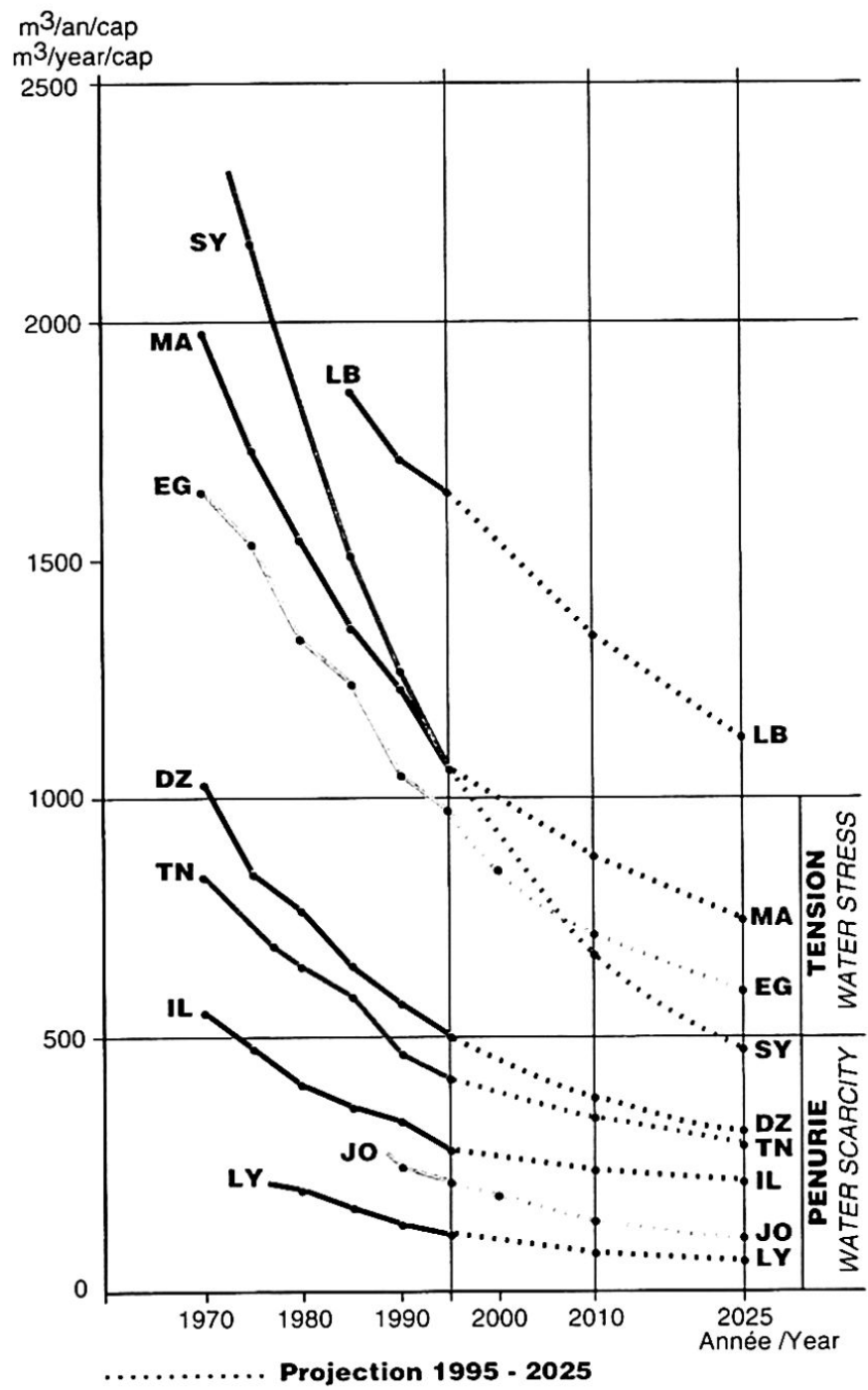

Fig.3: Annual decrease of water resources per inhabitant in selected mediterranean countries Chute des ressources en eau par habitants dans les pays méditerranéens Rückgang der Wasserressourcen pro Einwohner in ausgewählten Mittelmeerländern

Source: L'eau en région méditerranéenne, Centre d'activités régionales du Plan Bleu, Marseille, novembre 1996, p. 48. 
of the Middle Ages. History can only be of limited assistance here, as is obvious; it tells us that there were problems and that they were dealt with; it does not tell us whether the present-day resource limitation can be overcome, nor at what price.

The 20th century has witnessed unprecedented increases in water consumption and pressure on development activity in coastal areas. Given these trends, the question of their sustainability has inevitably been raised, even though history teaches us that societies have an extraordinary ability of using effective techniques to react to threats of water shortage. At this stage, however, it is still questionable whether or not the policy to be followed should be strictly dictated by the potential unavailability of natural resources. Policy decisions still enjoy a vast margin of choice. The natural limitations issue would seem to have been postponed for what could still be a very long time. It is likely that in the future the answer to the problem of agricultural or drinking water supply will continue to be a mix of measures including major transfer operations, adjusting provision prices (the only real way of saving water), reusing treated wastewater, and desalination.

The fundamental problem is still the ecological one, water in the environment. It is noticeable how rarely it is mentioned at conferences with wide media coverage which tend to bring together economic interests rather than environmental sensitivities. In a way, the idea of shortage is of interest to industry, the financial institutions, the major planners and engineering offices whose technical and economic formulae remain the same, even when anchored in the concept of «rational management of water resources». It is, therefore, to be expected that the question of shortage will remain on the agenda in the future whereas the aims and objectives may still not fully be operationalized and implemented.

\section{Epilogue}

In the Mediterranean, tourism and water are two major issues which illustrate the question of sustainable development and the limitation hypothesis in a way that simplifies it. Over the last three years the MCSD has tackled other questions where the issues are much less straightforward, due in particular to the lack of relevant indicators.

Thus, the urban issue is essential when one sees the rapid growth of cities like Athens, Cairo and Istanbul, and the related questions about the environment, quality of life and urban planning. However, how does one go about quantifying the relevant indicators of urban development which is becoming untolerable: air pollution, volume of waste, travel time, loss of urban amenities; they can be manifold and are not easily synthesised. It is clear that in including these questions on its agenda, the MCSD has taken on more complex subjects.
Let us finally deal with the institutions and policies of sustainable development. What institutions can be thought up to shoulder this inter-player, inter-ministerial question for which the criteria for assessment and decision-taking are still vague? The solution adopted by the United Nations and within the Mediterranean regional framework - an advisory Commission which brings together the players concerned - has the dual merit of being both ambitious and realistic. Its efficiency still remains to be seen. On this point, the results presented during the special session of the United Nations General Assembly in 1997, the so-called Rio+5, were not particularly encouraging as regards the United Nations Commission on Sustainable Development. In the year 2000-2001, the MCSD is scheduled to present its own report on the implementation of the Agenda Med 21. At the national level, Commissions on Sustainable Development have also been set up: this applies to France and Tunisia.

For its part, the European Union has adopted a Fifth action programme for the environment and sustainable development, which, under the aegis of the Directorate General for the Environment (DGXI), basically commits mainly that body. Within the Commission, it is striking to see the relative weight of services responsible for the internal market or competition, compared with those dealing with the environment. Thus, Greece which had set its import duties on used cars at a very high level in order to combat pollution, has recently been strongly encouraged to lower them because of the internal market.

Similarly, during recent negotiations with Switzerland, the European Commission strove to lower some of its environmental defences (ban on night transit for trucks, limited tonnages for heavy vehicles) in the name of free circulation of goods. Switzerland replied by promoting transalpine piggy-back transport. There is little scope for sustainable development concerns when the functioning of the market is at stake.

In Europe as elsewhere it is still difficult to have effective account be taken of environmental questions within development.

\section{Literature Cited}

BECK, C. (1998): Historical Sciences and Environmental Research (CNRS - «Environment, Life and Societies» program). - Letter n. 17.

Crouch, D.P. (1993): Water Management in Ancient Greek Cities. - New York: Oxford University Press.

Dorst, J. (1971): Avant que la nature meure: pour une écologie politique. - Neuchâtel: Delachaux and Niestlé. GodARD, O. (1994): Le développement durable, paysage intellectuel. - In: Nature Sciences Société. 4 (2): 309-322.

Goubert, J.-P. (1986): La conquête de l'eau: l'avènement de la santé à l'âge industriel. - Paris: Laffont. 
Grenon, M. \& M. Batisse, [ed.] (1989): Le Plan Bleu: avenirs du bassin Méditerrannéen. - Paris: Economica. Guilaine, J. (1991): Pour une archéologie agraire: à la croisée des sciences de l'homme et de la nature. - Paris: A. Colin.

Hardin, G. (1968): The Tragedy of the Commons. - In Dobson, A. [ed.] (1991): The green reader. - San Fransisco: Mercury House.

HUGHES, J.D. (1994): Pan's travail: Environmental problems of the ancient Greeks and Romans. - Baltimore: Johns Hopkins University.

LE Bras, H. (1994): Les limites de la planète: mythes de la nature et de la population. - Paris: Flammarion.

MarTin, R. (1956): L'urbanisme dans la Grèce antique. - Paris: Picard.

Thirgood, J.V. (1981): Man and the Mediterranean Forest. - London: Academic Press.

The views presented in this article do not necessarily represent the United Nations Environment Program and those of the Barcelona Convention.

\section{Summary: The Concept of Sustainable Development in the Mediterranean: \\ Emergence an Recurrence}

The history of the relationship between man and nature, since time immemorial, sets the scene for studying issues related to sustainable development. Concepts of «carrying capacity» and «ecological impact» are not new, as is illustrated by the example of the use of water resources in Ancient Greece. The Mediterranean region is particularly sensitive to such problems, and the protection of the Mediterranean sea was one of the first results to emerge from the Stockholm conference in 1972. The United Nations Environment Programme (UNEP), born after the conference, gave birth to the Mediterranean Action Plan, leading to the Barcelona Convention linking together twenty coastal states, as well as the European Union. In this framework, the Blue Plan was set up and designed to study the impacts on the environment of development and population growth. Several possible scenarios were set up, providing background material for the Earth Summit in Rio. The period between 1990 1995 saw the newly set up Mediterranean Commission dealing with issues relating to water (management, pollution), tourism (colonisation of natural sites, pressure on the environment) and sustainable management of coastal regions. Other points were also raised recently, such as sustainable urban development. However, this institutionalisation of environmental problems that happen at both the national and international levels, should not lead to a compromise statement achieving nothing concrete. Indeed, the maintenance of environmental achievements and the definition of new concepts should allow sustainable development to move forward.

\section{Résumé: Le concept de développement durable} en Méditerranée: émergence et récurrence

L'histoire des relations physiques homme-nature, depuis les temps les plus reculés, permet de mettre en perspective les questions concernant le développement durable. On voit en effet que les concepts de limite, de capacité de charge et d'impact écologique ne sont pas nouveaux, comme en témoigne, par exemple, le cas de l'utilisation des ressources en eau dans la Grèce antique. La région méditerranéenne est particulièrement sensible à ces problèmes, et sa protection a été l'un des premiers acquis de la Conférence de Stockholm, en 1972. Le PNUE, créé dans la foulée, a donné naissance au Plan d'action pour la Mediterranée, débouchant sur la Convention de Barcelone réunissant les vingt pays riverains et l'Union Européenne. Dans ce cadre, a été mis en place le Plan Bleu, structure destinée à étudier les impacts du développement sur l'environnement par la pression démographique. Divers scenarii (scenario tendanciel, scenario de développement maîtrisé) ont été établis, ce travail ayant contribué à nourrir la Conférence de Rio. La période 1990-1995 a vu la mise en place de la Commission méditerranéenne de développement durable traitant des question telles que l'eau (gestion, pollution), le tourisme (colonisation des sites naturels, pression sur l'environnement) et la gestion durable des zones côtières. D'autres points ont été soulevés récemment, comme celui du développement urbain durable. Pourtant, cette institutionnalisation des problèmes environnementaux, visible aussi bien aux niveaux étatiques qu'internationaux, ne devrait pas déboucher sur un discours consensuel qui n'engage à rien; le maintien des acquis environnementaux et la définition de nouveaux concepts devraient permettre de progresser dans la cause du développement durable.

\section{Zusammenfassung: Das Konzept der Nachhaltigen Entwicklung im Mittelmeerraum: Entstehung und Rekurrenz}

Die seit undenklichen Zeiten thematisierte Beziehung zwischen Mensch und Natur gibt diesem Text den Rahmen, anhand dessen Fragen der Nachhaltigen Entwicklung diskutiert werden. Dass Konzepte über feste Grenzen - wie beispielsweise die Tragfähigkeit oder die Auswirkungen auf das ökologische System - nicht neu sind, wird anhand eines Beispiels über die Verwendung der Wasserressourcen im Alten Griechenland gezeigt. Das Gebiet des Mittelmeerraums ist besonders empfänglich für Probleme dieser Art. Der Schutz des Mittelmeerraumes war eine der ersten Errungenschaften der Stockholm-Konferenz im Jahr 1972. Das «United Nations Environment Programme» (UNEP), das im Anschluss an die Konferenz entstand, ermöglichte die Ausarbeitung des «Mediterranean Action»-Plans, der zur Übereinkunft von Barcelona führte, die 20 Küstenregionen und die Europäische Union vereinte. Im Rahmen dieser Übereinkunft wurde der «Blue Plan« erar- 
beitet, anhand dessen die Auswirkungen der Entwicklung und des Bevölkerungswachstums auf die Umwelt untersucht wurden. Es wurden verschiedene Szenarien ausgearbeitet, die Material für den Weltgipfel in Rio lieferten. Im Zeitraum von 1990-1995 befasste sich die Mittelmeerraum-Kommission für Nachhaltige Entwicklung mit Fragen zu Themen wie Wasser, (Verwaltung, Verschmutzung), Tourismus (Kolonisation von Naturgebieten) und der Nachhaltigen Verwaltung von Küstengebieten. Weitere Themen, wie die Nachhaltige Entwicklung von Städten, wurden kürzlich aufgegriffen. Doch sollte diese Institutionalisierung der Umweltproblematik, die auf nationaler und internationaler Ebene stattfindet, nicht nur zu einer Konsensfindung auf dem Papier führen, sondern konkrete Ergebnisse liefern. Die Beibehaltung der Errungenschaften auf dem
Gebiet des Umweltschutzes und das Definieren neuer Ideen sollten die Nachhaltige Entwicklung weiter vorantreiben.

Prof. Lucien Chabason, Coordinator of «Plan d'action pour la Méditerranée», PNUE, 48, Vassileos Konstantinou, P.O. Box 18019, Athens 11610, Greece.

e-mail: chabason@unepmap.gr

Manuskripteingang/received/ rentrée du manuscrit: 5. Januar 1999 Annahme zum Druck/Accepted for publication/ acceptation à l'impression: 4. August 1999 